LAWRENCE LIVERMORE N A T IO N A L LABORATORY

SMALL-SCALE IMPACT SENSITIVITY TESTING ON EDC37

P. C. HSU, G. HUST, J. L. MAIENSCHEIN

May 2, 2008 
This document was prepared as an account of work sponsored by an agency of the United States government. Neither the United States government nor Lawrence Livermore National Security, LLC, nor any of their employees makes any warranty, expressed or implied, or assumes any legal liability or responsibility for the accuracy, completeness, or usefulness of any information, apparatus, product, or process disclosed, or represents that its use would not infringe privately owned rights. Reference herein to any specific commercial product, process, or service by trade name, trademark, manufacturer, or otherwise does not necessarily constitute or imply its endorsement, recommendation, or favoring by the United States government or Lawrence Livermore National Security, LLC. The views and opinions of authors expressed herein do not necessarily state or reflect those of the United States government or Lawrence Livermore National Security, LLC, and shall not be used for advertising or product endorsement purposes.

This work performed under the auspices of the U.S. Department of Energy by Lawrence Livermore National Laboratory under Contract DE-AC52-07NA27344. 


\title{
Small-scale Impact Sensitivity Testing on EDC37
}

\author{
P. C. Hsu*, G. Hust, and J. L. Maienschein, \\ Energetic Materials Center \\ Lawrence Livermore National Laboratory, Livermore, CA USA \\ Corresponding author; email: hsu7@1ln1.gov
}

\begin{abstract}
EDC37 was tested at LLNL to determine its impact sensitivity in the LLNL's drop hammer system. The results showed that impact sensitivities of the samples were between $86 \mathrm{~cm}$ and $156 \mathrm{~cm}$, depending on test methods.
\end{abstract}

Keywords: Explosives, impact sensitivity, drop hammer, EDC37

The work was performed under the auspices of U.S. Department of Energy by the Lawrence Livermore National Laboratory under Contract DE-AC52-07NA27344. 


\section{Introduction}

EDC37 is a plastic bonded explosive consisting of 90\% HMX, 1\% nitrocellulose and binder. We recently conducted impact sensitivity testing in our drop hammer system and the results are presented in this report.

2. System description and test method

Small-scale sensitivity testing was done to determine material response to various stimuli including impact, friction, and static spark. The impact sensitivity test system is briefly described below.

\subsection{Impact sensitivity test (drop hammer) system at LLNL}

ERL Type 12 drop hammer equipment at LLNL, shown in Figure 1, was used to determine the impact sensitivity [1]. The equipment includes a 2.5-kg drop weight, a striker (upper anvil, $2.5 \mathrm{~kg}$ for solid samples and $1.0 \mathrm{~kg}$ for liquid samples), a bottom anvil, a microphone sensor, and a peakmeter. For each drop, sample is placed on the bottom anvil surface and impacted by the drop weight from different heights. Signs of reactions upon impact are observed and recorded. These signs include noises, flashes or sparks, smoke, pressure, gas emissions, temperature rise due to exothermic reaction, color change of the sample, and changes to the anvil surface (noted by inspection). For solid samples, a "GO" was defined as a microphone sensor (for noise detection) response of $\geq 1.3 \mathrm{~V}$ as measured by a peakmeter. The higher the $\mathrm{DH}_{50}$ values, the lower the impact sensitivity. The method used to calculate $\mathrm{DH}_{50}$ values is the "up and down" or Bruceton method [23]. PETN and RDX have impact sensitivities of 15 and $35 \mathrm{~cm}$, respectively. TATB has impact sensitivity more than $177 \mathrm{~cm}$. For liquid samples, a "GO" was determined by the noise levels as measured by the peakmeter, appearance of flashes, temperature rise of the anvil, and visual inspection of the anvil surface. Figure 2 shows a "GO" event, flashes appeared as the drop weight impacted the sample.

\subsection{Test methods}

Three test methods are described in Table 1.

Table 1

\begin{tabular}{|c|c|c|}
\hline Test method* & Description & Note \\
\hline 1 & $\begin{array}{c}\text { Sample was placed on a 1" square } \\
\text { of carborundum sand paper (120 } \\
\text { grit) }\end{array}$ & $\begin{array}{c}\text { Thickness of the sand paper } \\
432 \mu \text {, which is the standard } \\
\text { method used at LLNL }\end{array}$ \\
\hline 2 & $\begin{array}{c}\text { Sample was placed on the bare } \\
\text { bottom anvil surface without } \\
\text { sample paper; greased top anvil } \\
\text { surface and bottom anvil surface; } \\
\text { grease layer thickness was 10 } \mu\end{array}$ & $\begin{array}{c}\text { Used Dow Corning silicone } \\
\text { vacuum grease }\end{array}$ \\
\hline 3 & $\begin{array}{c}\text { Sample was placed on a 1" square } \\
\text { of carborundum sand paper (120 } \\
\text { grit), also adhered a 1" square of } \\
\text { carborundum sand paper (120 grit) } \\
\text { on the top anvil }\end{array}$ & $\begin{array}{c}\text { Thickness of the sand paper } \\
432 \mu\end{array}$ \\
\hline
\end{tabular}

* The tests were performed at ambient condition $\left(72^{\circ} \mathrm{F}, 40 \%\right.$ R.H. $)$ by the same technician. 


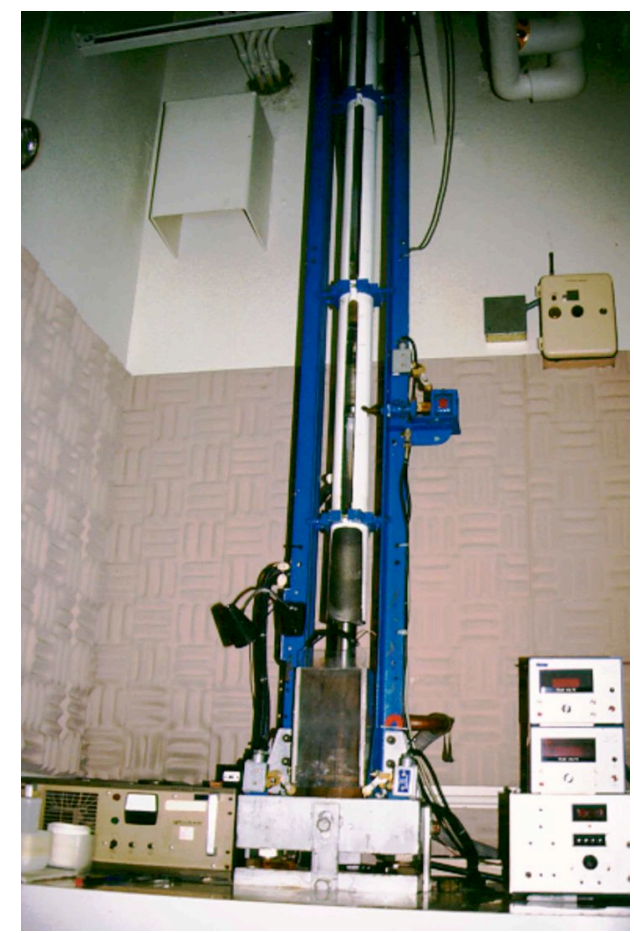

Figure 1. Drop hammer system at LLNL

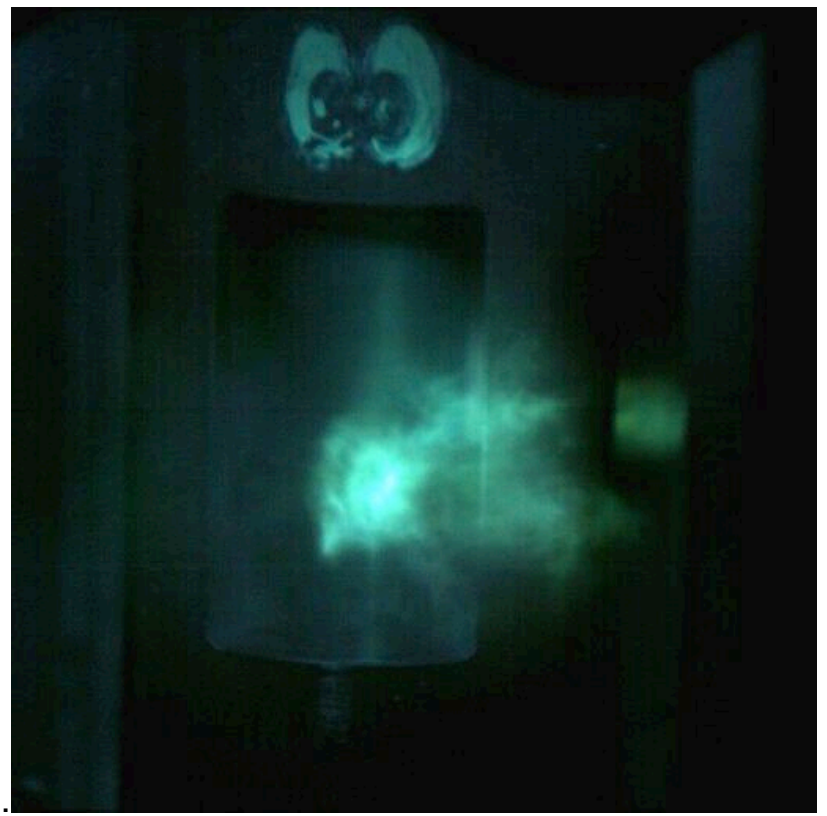

Figure 2. A "GO" event observed during the impact sensitivity test; flashes appeared as the drop weight impacted the sample. 


\section{Test results}

Results of the impact sensitivity testing on EDC37 are listed in Tables 2, 3, and 4 for methods 1, 2, and 3, respectively. The impact sensitivities $\left(\mathrm{DH}_{50}\right)$ for EDC37 varied from $86 \mathrm{~cm}$ to $158 \mathrm{~cm}$, depending on the test methods. The reason why by greasing the anvils and sand papering the top anvil increased the drop hammer value was not clear. One possible explanation is that by greasing, the EDC 37 particles were lubricated and hence the impact sensitivity was reduced (i.e. $\mathrm{DH}_{50}$ went up). More study is needed to draw more concrete explanation.

Table 2: $\mathrm{DH}_{50}$ (impact sensitivity for test method 1): $86 \mathrm{~cm}$

\begin{tabular}{|c|c|c|}
\hline Drop weight heights, $c m$ & Number of "GO" events & Number of "NO-GO" events \\
\hline 50 & 0 & 3 \\
\hline 62.9 & 2 & 4 \\
\hline 79.2 & 4 & 1 \\
\hline 99.7 & 1 & 0 \\
\hline
\end{tabular}

Table 3: $\mathrm{DH}_{50}$ (impact sensitivity for test method 2; greased top and bottom anvils; no sand paper): $154 \mathrm{~cm}$

\begin{tabular}{|c|c|c|}
\hline Drop weight heights, cm & Number of "GO" events & Number of "NO-GO" events \\
\hline 111.9 & 0 & 3 \\
\hline 125.6 & 4 & 4 \\
\hline 140.9 & 4 & 4 \\
\hline 158.1 & 4 & 2 \\
\hline 177.4 & 2 & 3 \\
\hline
\end{tabular}

Table 4: $\mathrm{DH}_{50}$ (impact sensitivity for test method 3; sand paper was placed on the top and the bottom anvils): $158 \mathrm{~cm}$

\begin{tabular}{|c|c|c|}
\hline Drop weight heights, cm & Number of "GO" events & Number of "NO-GO" events \\
\hline 111.9 & 0 & 3 \\
\hline 125.6 & 4 & 4 \\
\hline 140.9 & 4 & 4 \\
\hline 158.1 & 4 & 2 \\
\hline 177.4 & 2 & 3 \\
\hline
\end{tabular}

References

1. Simpson, L. R. and Foltz, M.F., "LLNL Small-Scale Drop-Hammer Impact Sensitivity Test,” UCRL-ID-119665, 1995.

2. Dixon, W.J. and Massey, F.J., "Introduction to Statistical Analysis, 2nd ed., McGraw-Hill, New York, pp 318-327, 1957.

3. Dixon, W.J., "The Up and Down Method for Small Samples," J. Am. Statistical Assoc., 60, pp 967-978, 1965. 